\title{
Biodiversity of psychrotrophic microbes and their biotechnological applications
}

\author{
Ajar Nath Yadav ${ }^{1 *}$, Neelam Yadav², Shashwati Ghosh Sachan³, Anil Kumar Saxena ${ }^{4}$ \\ ${ }^{1}$ Department of Biotechnology, Akal College of Agriculture, Eternal University, Baru Sahib, Himachal Pradesh, India, ${ }^{2}$ Gopi Nath P. G. College, Veer Bahadur \\ Singh Purvanchal University, Uttar Pradesh, India, ${ }^{3}$ Department of Bio-Engineering, Birla Institute of Technology, Ranchi, Jharkhand, India, ${ }^{4}$ ICAR-National \\ Bureau of Agriculturally Important Microorganisms, Mau, Uttar Pradesh, India
}

\begin{tabular}{|c|c|}
\hline ARTICLE INFO & ABSTRACT \\
\hline $\begin{array}{l}\text { Article history: } \\
\text { Received on: December 02, } 2018 \\
\text { Accepted on: January 16, } 2019 \\
\text { Available online: July 04, } 2019\end{array}$ & $\begin{array}{l}\text { The extreme cold environments harbor novel psychrotrophic microbes. The psychrotrophic microbes have been reported } \\
\text { as plant growth promoters and biocontrol agents for sustainable agriculture, in industry as cold-adapted hydrolytic } \\
\text { enzymes and in medicine as secondary metabolites and pharmaceutical important bioactive compounds. Inoculation } \\
\text { with psychrotrophic/psychrotolerant strains significantly enhanced root/shoot biomass and nutrients uptake as compared }\end{array}$ \\
\hline $\begin{array}{l}\text { Key words: } \\
\text { Adaptation, } \\
\text { Biodiversity, } \\
\text { Biotechnological applications, } \\
\text { Cold adapted, } \\
\text { Psychrotrophic }\end{array}$ & $\begin{array}{l}\text { to non-bacterized control. The psychrotrophic microbes play important role in alleviation of cold stress in plant growing } \\
\text { at high hill and low temperature and conditions. The psychrotrophic microbes have been reported from worldwide } \\
\text { from cold habitats and belong to all three domain archaea, bacteria, and eukarya including different phylum such as } \\
\text { Actinobacteria, Ascomycota, Bacteroidetes, Basidiomycota, Chloroflexi, Chlamydiae, Planctomycetes, Cyanobacteria, } \\
\text { Euryarchaeota, Firmicutes, Gemmatimonadetes, Verrucomicrobia, Mucoromycota, Proteobacteria, Spirochaetes, } \\
\text { Thaumarchaeota and Nitrospirae. The most dominant genera belong to Arthrobacter, Bacillus, Exiguobacterium, } \\
\text { Paenibacillus, Providencia, Pseudomonas, and Serratia have been reported from the cold habitats. The Psychrotrophic } \\
\text { microbes have biotechnological applications in agriculture, medicine, industry, food, and allied sectors. }\end{array}$ \\
\hline
\end{tabular}

\section{INTRODUCTION}

The extreme environment of low temperature is one of the major abiotic stresses acting as the limiting factor affecting the agricultural productivity. $20 \%$ of the Earth's surfaces were covered frozen soils (permafrost), glaciers and ice sheets, and snow cover area. Extreme low temperature represents unique ecosystems which harbor novel biodiversity which has been extensively investigated in the past few years with a focus on culture-dependent and culture-independent techniques [1-6]. The psychrotrophic microbes have been reported from all three domains of life archaea, bacteria, and eukarya and belong to different phylum, namely Actinobacteria, Planctomycetes, Acidobacteria, Ascomycota, Bacteroidetes, Spirochaetes, Basidiomycota, Chlamydiae, Chloroflexi, Nitrospirae, Cyanobacteria, Verrucomicrobia, Firmicutes, Gemmatimonadetes, Mucoromycota, Proteobacteria, Thaumarchaeota, and Euryarchaeota [3-10]. The microbial diversity has opened up new possibilities for potential biotechnological agricultural and industrial applications of beneficial and efficient microbes for diverse sectors including agriculture,

\footnotetext{
*Corresponding Author:

Dr. Ajar Nath Yadav,

Department of Biotechnology,

Akal College of Agriculture, Eternal University, Baru Sahib, Himachal

Pradesh, India. Phone: +91-9882545085.

Email:ajar@eternaluniversity.edu.in
}

industry, and medicine. The cold-adapted microbes attracted the attention of the scientific community due to their aptitude in plant growth promotion, adaptation of plants at low-temperature conditions.

The novel microbes have been isolated using the culturedependent techniques from cold environments worldwide including Actinoalloteichus spitiensis, RMV-378 ${ }^{\mathrm{T}}$ [11], Agrococcus lahaulensis, $\mathrm{K} 22-21^{\mathrm{T}} \quad[12]$, Arthrobacter psychrochitiniphilus, $\mathrm{GP}^{\mathrm{T}}$ [13], Azospirillum himalayense, ptl-3 ${ }^{\mathrm{T}}$ [14], Bacillus lehensis, MLB2 $^{\mathrm{T}}$ [15], Desulforhopalus vacuolatus, 1tk10 [16], Dioszegia antarctica, ANT-03-116 ${ }^{\mathrm{T}}$ [17], Exiguobacterium himgiriensis, K22-26 ${ }^{\mathrm{T}}$ [18], Exiguobacterium soli, DVS $3 \mathrm{Y}^{\mathrm{T}}$ [19], Flavobacterium frigidarium, $\mathrm{A} 2 \mathrm{i}^{\mathrm{T}}$ [20], Flavobacterium omnivorum, $\mathrm{ZF}-8^{\mathrm{T}}$ [21], Flavobacterium phocarum, SE14 ${ }^{\mathrm{T}}$ [22], Flavobacterium urumqiense, $\mathrm{Sr} 25^{\mathrm{T}}$ [23], Gelidibacter algens, ACAM 536 [24], Geopsychrobacter electrodiphilus, A1 ${ }^{\mathrm{T}}$ [25], Glaciecola pallidula, ACAM 615 ${ }^{\mathrm{T}}$ [26], Glaciimonas frigoris, N1-38 [27], Halobacterium lacusprofundi, ACAM $32^{\mathrm{T}}$ [28], Hymenobacter rubripertinctus, NY03-3-30 $0^{\mathrm{T}}$ [29], Massilia eurypsychrophila, B528-3 ${ }^{\mathrm{T}}$ [30], Nocardiopsis antarcticus [31], Paenibacillus glacialis, KFC91 ${ }^{\mathrm{T}}$ [6], Pedobacter arcticus, $\mathrm{A} 12^{\mathrm{T}}$ [32], Pseudomonas deceptionensis, $\mathrm{M}^{\mathrm{T}}$ [33], Psychrobacter pocilloporae, S6-60 ${ }^{\mathrm{T}}$ [34], Sphingobacterium antarcticus, 4BY [35], and Sulfitobacter brevis, EL-162 ${ }^{\mathrm{T}}$ [Table 1] [36].

The cold habitats such as cold deserts, glaciers, and subglacial lakes are hot spots of a great microbial diversity of psychrophilic, psychrotolerant, 
Table 1: Novel psychrotrophic microbes from diverse cold habitats

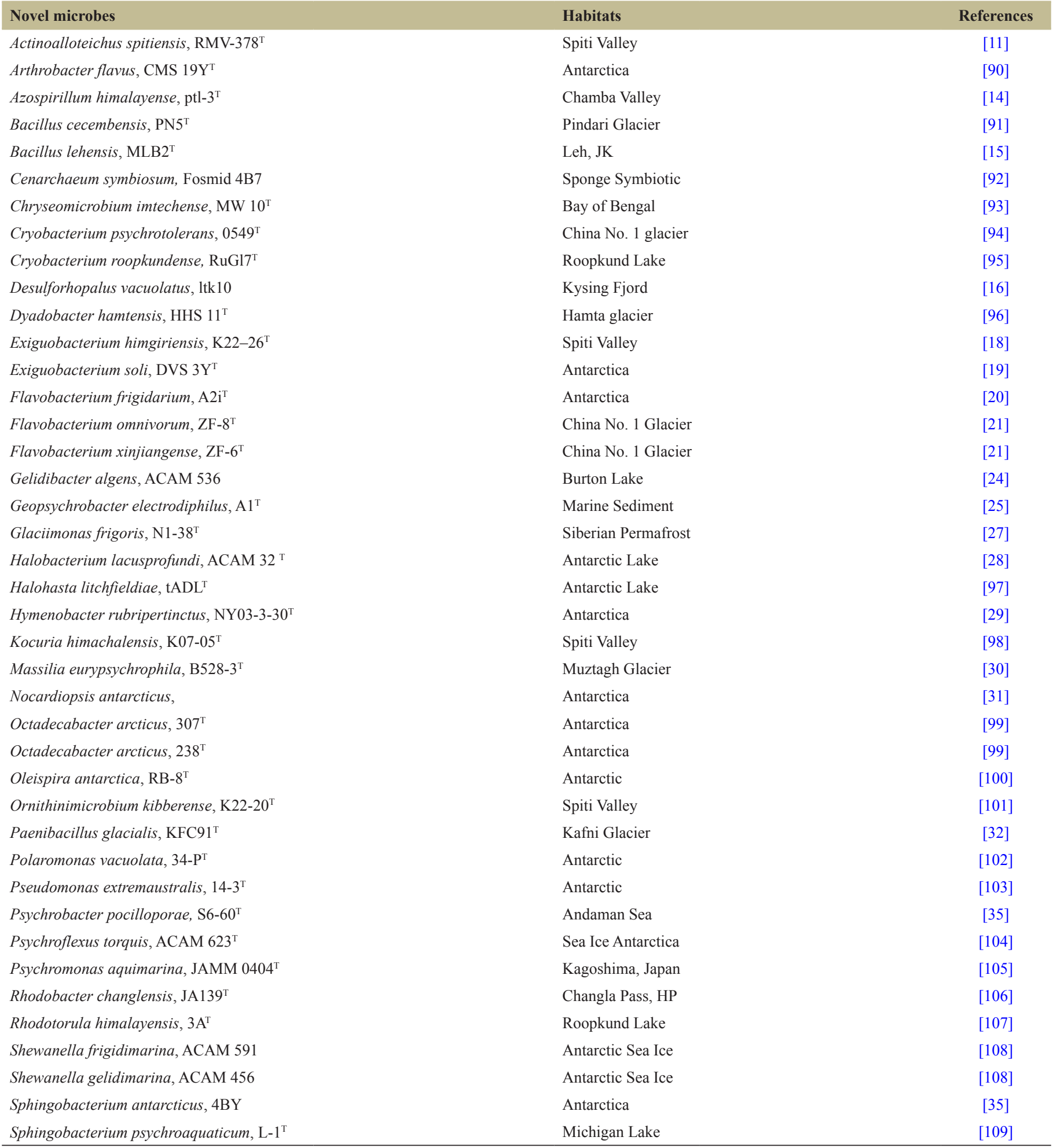

and psychrotrophic microbiomes. The cold-adapted microbes possess diverse genes responsible for cold adaptation and genes for diverse molecules and alleles with potential applications in diverse fields. There are several reports on whole genome sequences of novel and potential psychrotrophic microbes such as Arthrobacter agilis [37], Cenarchaeum symbiosum [38], Clavibacter sp. [39], Colwellia chukchansi [40], Colwellia psychrerythraea [41], Exiguobacterium antarcticum [42], Exiguobacteriumoxidotolerans [43], Exiguobacterium sibiricum [44], Methanococcoides burtonii [45], Octadecabacter antarcticus [46], Paenibacillus sp. [47], Planomicrobium glaciei [48], and Rheinheimera sp. [Table 2] [49]. The whole genome sequences of cold-adapted microbes help to understand the adaptation on microbe under the extreme cold habitats and also potential genes for functional attributes, for example, A. agilis L77, are an important psychrophilic 
Table 2: Genome sequencing of psychrophilic and psychrotrophic microbes isolated from diverse cold habitats worldwide

\begin{tabular}{|c|c|c|c|c|c|}
\hline Psychrotrophic microbes & Source & Size (Mb) & $\mathrm{G}+\mathrm{C}(\%)$ & CDS & References \\
\hline Acinetobacter sp. & Lahaul-Spiti & 4.31 & 40.75 & 4017 & {$[110]$} \\
\hline Arsukibacterium ikkense & Cold Habitat & 4.13 & 49.7 & 3605 & [111] \\
\hline Arthrobacter alpines & Sikkim & 4.30 & 60.64 & 4154 & {$[112]$} \\
\hline Arthrobacter sp. & Chandra Tal & 3.60 & 58.97 & 3454 & [113] \\
\hline Colwellia polaris & Canada & 4.43 & 37.5 & 3686 & {$[40]$} \\
\hline Colwellia psychrerythraea & Sea Ice, Arctic & 5.37 & 38.00 & 4634 & [41] \\
\hline $\begin{array}{l}\text { Cryobacterium } \\
\text { roopkundensis }\end{array}$ & Roopkund & 4.36 & 65.30 & 4048 & {$[114]$} \\
\hline Exiguobacterium antarcticum & Lake Fryxell & 2.82 & 47.50 & 2746 & [42] \\
\hline Methanococcoides burtonii & Ace Lake & 2.54 & 44.08 & 2406 & {$[45]$} \\
\hline Microterricola viridarii & Glacier & 3.70 & 68.70 & 3456 & {$[117]$} \\
\hline Nesterenkonia sp. & Permafrost & 3.70 & 69.50 & 2886 & {$[118]$} \\
\hline Octadecabacter antarcticus & Sea Ice, Arctic & 4.81 & 54.60 & 4428 & {$[46]$} \\
\hline Paenibacillus & Lahaul-Spiti & 8.44 & 50.77 & 7335 & [119] \\
\hline Planomicrobium glaciei & Chandra River & 3.90 & 46.97 & 3934 & {$[48]$} \\
\hline Pseudomonas trivialis & Lahaul-Spiti & 6.45 & 59.91 & 6032 & {$[120]$} \\
\hline Rheinheimera sp. & Pangong Lake & 4.52 & 46.23 & 3942 & [49] \\
\hline Saccharomyces eubayanus & Cold Habitat & 1.27 & 39.60 & 589 & [121] \\
\hline
\end{tabular}

CDS: Coding sequence

bacteria isolated from Pangong lake, Northwest (NW) Himalayas, India. The strain $\mathrm{L} 77$ has abilities to produced cold-adapted hydrolytic enzymes and shows that the plant growth-promoting (PGP) attributes are different low-temperature conditions. The whole genome sequences of psychrophilic bacteria revealed different genes for adaptation and metabolic activities [37]. The novel psychrophilic/psychrotolerant microbes and their products will be applicable in broad range of agricultural, industrial, and medical processes. The cold-tolerant psychrotrophic microbes can be valuable in agriculture as inoculants biofertilizers and biocontrol agents. The present review describes the microbial diversity analysis from cold habitats and its potential applications in agriculture, industry, medicine, and allied sectors.

\section{BIODIVERSITY PSYCHROTROPHIC MICROBES}

The extreme of cold represents hot spots of microbial biodiversity for psychrotrophic, psychrophilic, and psychrotolerant microbiomes $[9,50,51]$. The biodiversity of psychrotrophic microbes inhabiting cold habitats has been extensively investigated worldwide and has been reported from phylum, namely Actinobacteria, Gemmatimonadetes, Ascomycota, Acidobacteria, Bacteroidetes, Basidiomycota, Chlamydiae, Chloroflexi, Proteobacteria, Cyanobacteria, Firmicutes, Mucoromycota, Verrucomicrobia, Nitrospirae, Planctomycetes, Spirochaetes, Thaumarchaeota, and Euryarchaeota [Figure 1]. The microbiomes of cold habitats including the subglacial lakes, Antarctic, Arctic glacier, permanently ice-covered sea, permafrost, and Himalayan and Mountain lakes have been investigated for the diversity of psychrotrophic, psychrophilic, and psychrotolerant microbes [52-56,19,57-62].

The biodiversity of cold-adapted bacteria was deciphered from northern hills zone of India. A total of 247 culturable bacteria have been isolated using serial dilution and spread plate methods from different sites in Indian Himalayan regions. The bacteria have been identified using 16S rRNA gene sequencing and BLAST analysis. All sequences have been analyzed for phylogenetic profiling and revealed that the sequences are affiliated to four phyla, namely Firmicutes, Proteobacteria, Bacteroidetes, and Actinobacteria. The selected strains have been found to be PGP attributes, which included phosphorus, $\mathrm{K}$, and $\mathrm{Zn}$ solubilization; $\mathrm{NH}_{3}, \mathrm{HCN}$, indole-3-acetic acid $\left(\mathrm{C}_{10} \mathrm{H}_{9} \mathrm{NO}_{2}\right)$, and Fe-chelating compounds production; and the activity of 1-aminocyclopropane-1-carboxylate (ACC) deaminase and biological nitrogen fixation. The psychrotrophic bacteria also possess biological control against the different pathogens such as Macrophomina phaseolina, Rhizoctonia solani, and Fusarium graminearum. These PGP psychrotrophic and psychrotolerant bacteria could be applicable as biofertilizers and biocontrol agents for crops cultivated under the low-temperature conditions and hilly regions [2].

The Indian cold deserts are suitable for the selection of psychrotrophic and psychrotolerant bacteria, archaea, and fungi with potential biotechnological application in diverse sectors, microbes. Yadav et al. [63] investigated microbiome of the cold deserts of Northwestern Himalayas, India, using culture-dependent and culture-independent 


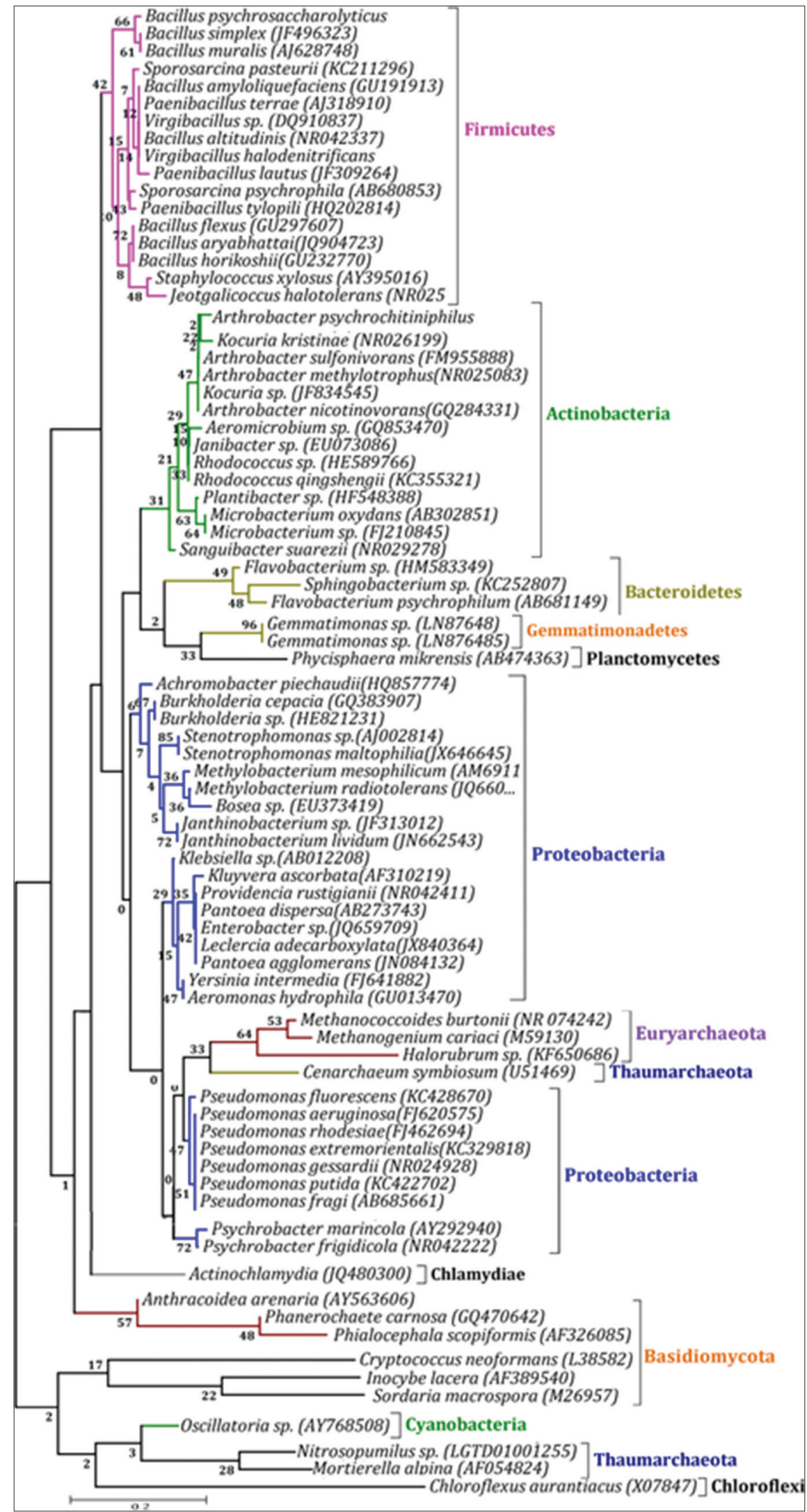

Figure 1: Phylogenetic tree showed the relationship among psychrotrophic, isolated from diverse cold habitats worldwide

method and reported different genera, belonging to different phyla, namely Bacteroidetes, Firmicutes, Actinobacteria, and Proteobacteria.
The selected microbe showed PGP attributes of the production of $\mathrm{NH}_{3}, \mathrm{HCN}$, gibberellic acid, Fe-chelating compounds (catecholates 
[phenolates], hydroxamates, and carboxylates), and indole acetic acids; $P$, $\mathrm{K}$, and $\mathrm{Zn}$ solubilization and ACC deaminase activity. The microbiomes with psychrotrophic ability with different PGP traits may be used as biofertilizers/bioinoculants and biocontrol agents for hilly crops. The report by Yadav et al. [63] shows the presence of Pseudomonas cedrina, Brevundimonas terrae, Arthrobacter nicotianae, and Paenibacillus tylopili in cold habitats for the $1^{\text {st }}$ time and exhibits multifarious PGP attributes at low-temperature conditions. In another investigation by Yadav et al. [64], the culturable biodiversity of microbiomes in Leh Ladakh region and found that bacteria belong to four phyla, namely Proteobacteria, Firmicutes, Bacteroidetes, and Actinobacteria which included different genera Bacillus, Desemzia, Pseudomonas, Sporosarcina, Arthrobacter, Psychrobacter, Exiguobacterium, Flavobacterium, Alishewanella, Staphylococcus, Brachybacterium, Klebsiella, Providencia, Paracoccus, Planococcus, Sinobaca, Janthinobacterium, Sphingobacterium, Kocuria, Aurantimonas, Citricoccus, Cellulosimicrobium, Brevundimonas, Stenotrophomonas, Vibrio, and Sanguibacter. These microbes possess PGP attributes and may be applicable as bioinoculants and biocontrol for crops in hilly area.

The subglacial lakes are also hot spots of microbial diversity of psychrotrophic and psychrotolerant bacteria with functional attributes of cold-adapted and cold stable active extracellular hydrolytic enzymes productions [65]. On the basis of DNA isolation, polymerase chain reaction amplification of $16 \mathrm{~S}$ rRNA gene and their sequencing using universal primers reveled that isolated bacilli belong to different genera, namely Exiguobacterium, Virgibacillus, Staphylococcus, Lysinibacillus, Jeotgalicoccus, Desemzia, Bacillus, Paenibacillus, Planococcus, Pontibacillus, Sinobaca, and Sporosarcina. The identified genera affiliated to different families Bacillales incertae sedis, Carnobacteriaceae, Bacillaceae, Planococcaceae, Paenibacillaceae, Staphylococcaceae, and Sporolactobacillaceae. The selected isolates found to exhibit cold-active enzymes such as amylase, chitinase, pectinase, $\beta$-glucosidase, protease, cellulase, xylanase, $\beta$-galactosidase, laccase, and lipase by different genera, namely P. terrae, Bacillus amyloliquefaciens, Exiguobacterium indicum, Bacillus marisflavi, Pontibacillus sp., Sporosarcina globispora, and Sporosarcina psychrophila.

The PGP psychrotrophic bacilli were investigated from different sites in NW Himalayas India [66] and bacteria have been reported from different genera, namely Desemzia, Exiguobacterium, Lysinibacillus, Sporosarcina, Jeotgalicoccus, Planococcus, Paenibacillus, Sinobaca, Pontibacillus, Staphylococcus, and Virgibacillus. Among all the identified bacterial strains, Bacillus muralis, Bacillus licheniformis, Sporosarcina globispora, P. tylopili, and Desemzia incerta, were found to be an important biofertilizers for Indian Himalayan agriculture.

Cold-adapted microbes are ubiquitous in nature and can be isolated from permanently ice-covered lakes, cloud glaciers, and hilly regions [8]. Microbes recovered using isolation techniques using different growth media as selective and complex and using 16S rRNA gene sequencing the bacteria were affiliated to genera Stenotrophomonas, Virgibacillus, Citricoccus, Enterobacter, Brevundimonas, Providencia, Pseudomonas, Flavobacterium, Pantoea, Planococcus, Paenibacillus, Pontibacillus, Methylobacterium, Psychrobacter, Cellulosimicrobium, Exiguobacterium, Janthinobacterium, Lysinibacillus, Rhodococcus, Sanguibacter, Arthrobacter, Sphingobacterium, Bacillus, Staphylococcus, and Sporosarcina. The identified bacteria affiliated to different phylum on the phylogenetic profiling using Actinobacteria, Proteobacteria, Basidiomycota, Chlamydiae, Chloroflexi, Bacteroidetes, Cyanobacteria, and Firmicutes using Mega 4 analysis.
Cold-adapted microbial communities can be studies using culturedependent and culture-independent techniques. The microbiomes reported using both techniques culture dependent and culture independent revealed the occurrence of different and diverse major groups viz., Actinobacteria, Ascomycota, Bacteroidetes, Verrucomicrobia, Thaumarchaeota, Spirochaetes, Proteobacteria, Planctomycetes, Nitrospirae, Mucoromycota, Gemmatimonadetes, Firmicutes, Euryarchaeota, Cyanobacteria, Chloroflexi, Chlamydiae, and Basidiomycota. On review of isolated cold-adapted microbes, it was found that proteobacteria were most dominant phylum followed by Firmicutes and Actinobacteria [10].

\section{BIOTECHNOLOGICAL APPLICATIONS}

The psychrotrophic microbes exhibited multifarious PGP attributes such as ACC deaminase activity, potassium zinc and phosphorus solubilization, biological $\mathrm{N}_{2}$ fixation, and production of different bioactive compounds such as gibberellic acids, ammonia, cytokinins, Fe-chelating compounds, hydrogen cyanide, and indole-3-acetic acid. The use of PGP microbes improves plant growth by supplying plant nutrients, which can help sustain environmental health and soil productivity [10]. Psychrotrophic PGP microbes were found in several genera, including Arthrobacter, Bacillus, Burkholderia, Pseudomonas, Exiguobacterium, Janthinobacterium, Lysinibacillus, Methylobacterium, Microbacterium, Paenibacillus, Providencia, and Serratia [67-70]. The microbes having ACC deaminase activity help plant to alleviate cold stress [Table 3] [2,66,71,72].

Sustainable agriculture requires the use of strategies to increase or maintain the current rate of crops and food production using ecofriendly manners. PGP microbe can affect plant growth directly under the low-temperature condition through nitrogen-fixing bacteria

Table 3: Psychrotrophic microbes with multifunctional plant growth promoting attributes

\begin{tabular}{lcccc} 
Psychrotrophic microbes & P & Sid & ACC & References \\
Aeromonas hydrophila & $31.5 \pm 1.8$ & + & - & {$[63]$} \\
Arthrobacter methylotrophus & $55.9 \pm 1.4$ & + & + & {$[2]$} \\
Arthrobacter sulfonivorans & $25.6 \pm 1.2$ & + & - & {$[64]$} \\
Bacillus amyloliquefaciens & $54.2 \pm 1.5$ & + & + & {$[123]$} \\
Bacillus firmus & $35.2 \pm 3.3$ & + & + & {$[64]$} \\
Bacillus licheniformis & $19.2 \pm 1.0$ & + & & {$[66]$} \\
Bacillus pumilus & $36.1 \pm 0.8$ & + & - & {$[64]$} \\
Bacillus subtilis & $19.8 \pm 0.5$ & + & + & {$[64]$} \\
Cellulosimicrobium cellulans & $15.5 \pm 1.1$ & - & + & {$[64]$} \\
Desemzia incerta & $47.5 \pm 1.2$ & + & - & {$[64]$} \\
Paenibacillus tylopili & $48.4 \pm 2.4$ & + & - & {$[66]$} \\
Pantoea dispersa & $44.5 \pm 0.2$ & + & - & {$[124]$} \\
Pseudomonas fluorescens & $768.3 \pm 0.2$ & - & - & {$[125]$} \\
Pseudomonas fluorescens & $90.2 \pm 1.7$ & + & - & {$[126]$} \\
Pseudomonas fragi CS11RH1 & $514.9 \pm 0.2$ & - & - & {$[127]$} \\
Pseudomonas vancouverensis & $66.3 \pm 0.2$ & + & & {$[128]$} \\
Rahnella sp. & $805.0 \pm 1$. & + & + & {$[129]$} \\
Sanguibacter antarcticus & $20.1 \pm 0.1$ & + & + & {$[64]$} \\
Sanguibacter suarezii & $18.1 \pm 0.5$ & + & + & {$[63]$} \\
Stenotrophomonas maltophilia & $55.7 \pm 0.5$ & + & + & {$[2]$} \\
\hline P. & + &
\end{tabular}

P: Phosphorus, Sid: Siderophores, ACC: 1-aminocyclopropane-1-carboxylate 
such as Arthrobacter, Azoarcus, Azospirillum, Azotobacter, Bacillus, Enterobacter, Gluconacetobacter, Herbaspirillum, Klebsiella, Pseudomonas, and Serratia [1,2,69,73,74]; ACC deaminase activity by Acinetobacter, Achromobacter, Agrobacterium, Alcaligenes, Azospirillum, Bacillus, Burkholderia, Enterobacter, Pseudomonas, Ralstonia, Serratia, and Rhizobium [75-78] and through indirect mechanism by releasing siderophores, $\beta-1,3$-glucanase, chitinases, antibiotics, and fluorescent pigment or by cyanide production by Alcaligenes sp., Bacillus pumilus, B. subtilis, B. megaterium, Clavibacter michiganensis, Curtobacterium sp., Flavobacterium sp., Kluyvera sp., Microbacterium sp., Pseudomonas alcaligenes, P. putida, and P. fluorescens [79-85].

The psychrophilic, psychrotolerant, and psychrotrophic microbes are important for many reasons, particularly because they exhibited antifreezing compounds, antibiotics, and bioactive compounds production [1] and production of extracellular hydrolytic enzymes with potential biotechnological applications in different processes. These enzymes included $\beta$-glucosidase, $\beta$-galactosidase, xylanase, protease, pectinase, laccase, lipase, chitinase, cellulase, and amylase $[37,65,86]$. Cold-active enzymes are produced by psychrophilic microbes, namely Acinetobacter, Aquaspirillum, Arthrobacter, Moraxella, Bacillus, Moritella, Carnobacterium, Planococcus, Clostridium, Cytophaga, Shewanella, Vibrio, Flavobacterium, Marinomonas, Paenibacillus, Pseudoalteromonas, Pseudomonas, Psychrobacter, and Xanthomonas [9,37,65,87-89]. Enzymes from psychrophilic and psychrotrophic microbes have become interesting for different processes in industry, pharmaceuticals, medicine, and food and feed industry. Antifreezing compounds from psychrophilic microbes are useful in cryosurgery and also in the cryopreservation of whole organisms, isolated organs, cell lines, and tissues [1,9,37].

\section{CONCLUSION AND FUTURE VISION}

The psychrophilic, psychrotolerant and psychrotrophic microbiomes have been isolated from different cold habitats worldwide. The microbial diversity of cold environments has attracted the consideration of the scientific community dues to production of cold active enzymes production, anti-freezing compounds, secondary metabolites and bioactive compounds by psychrotrophic microbes. The psychrotolerant/ psychrotrophic microbes have potential biotechnological applications in industry, pharmaceuticals, medicine, food and feed for human. The psychrotrophic microbes with multifarious

PGP attributes could be used as biofertilizers and biocontrol agents for crops growing in hilly and low temperature condition for enhance crops production and soil health for sustainable agriculture. The psychrotrophic microbes having biodegradation ability could be used for bioremediation, and waste water treatments for sustainable environments. These coldadapted microbes may be used for biofuels and biodiesel production for future energy systems. The psychrotrophic microbiomes are widely distributed and have been reported to promote plant growth and alleviation of cold stress in plants. Although the most research work conducted so far has largely focused on psychrophilic and psychrotolerant microbes, it is a welcome sign that many agriculturally important resourceful microbes are being described from various parts of the earth.

\section{ACKNOWLEDGMENT}

The authors are grateful to Prof. Harcharan Singh Dhaliwal, Vice Chancellor, Eternal University, Baru Sahib, Himachal Pradesh, India, for providing infrastructural facilities and constant encouragement.

\section{REFERENCES}

1. Yadav AN. Bacterial Diversity of Cold Deserts and Mining of Genes for Low Temperature Tolerance. New Delhi/BIT, Ranchi: Ph.D. Thesis, IARI; 2015; DOI: 10.13140/RG.2.1.2948.1283/2.

2. Verma P, Yadav AN, Khannam KS, Panjiar N, Kumar S, Saxena AK, et al. Assessment of genetic diversity and plant growth promoting attributes of psychrotolerant bacteria allied with wheat (Triticum aestivum) from the Northern Hills zone of India. Ann Microbiol 2015;65:1885-99.

3. Frühling A, Schumann P, Hippe H, Sträubler B, Stackebrandt E. Exiguobacterium undae sp. nov. and Exiguobacterium antarcticum sp. nov. Int J Syst Evol Microbiol 2002;52:1171-6.

4. Shivaji S, Reddy GS, Suresh K, Gupta P, Chintalapati S, Schumann P, et al. Psychrobacter vallis sp. nov. and Psychrobacter aquaticus sp. nov. from antarctica. Int J Syst Evol Microbiol 2005;55:757-62.

5. Mayilraj S, Krishnamurthi S, Saha P, Saini HS. Rhodococcus kroppenstedtii sp. nov. a novel actinobacterium isolated from a cold desert of the himalayas, India. Int J Syst Evol Microbiol 2006;56:979-82.

6. Kishore KH, Begum Z, Pathan AA, Shivaji S. Paenibacillus glacialis sp. nov. isolated from the Kafni Glacier of the Himalayas, India. Int J Syst Evol Microbiol 2010;60:1909-13.

7. Yadav AN, Kumar R, Kumar S, Kumar V, Sugitha T, Singh B, et al. Beneficial microbiomes: Biodiversity and potential biotechnological applications for sustainable agriculture and human health. J Appl Biol Biotechnol 2017;5:1-13.

8. Yadav AN, Verma P, Sachan SG, Saxena AK. Biodiversity and biotechnological applications of psychrotrophic microbes isolated from Indian Himalayan regions. EC Microbiol 2017;1:48-54.

9. Yadav AN, Verma P, Kumar V, Sachan SG, Saxena AK. Extreme cold environments: A suitable niche for selection of novel psychrotrophic microbes for biotechnological applications. Adv Biotechnol Microbiol 2017;2:1-4.

10. Yadav AN, Verma P, Sachan SG, Kaushik R, Saxena AK. Psychrotrophic microbiomes: Molecular diversity and beneficial role in plant growth promotion and soil health. In: Panpatte DG, Jhala YK, Shelat HN, Vyas RV. Microorganisms for Green Revolution. Volume 2. Microbes for Sustainable Agro-ecosystem. Singapore: Springer; 2018. p. 197-240.

11. Singla AK, Mayilraj S, Kudo T, Krishnamurthi S, Prasad GS, Vohra RM, et al. Actinoalloteichus spitiensis sp. nov. a novel actinobacterium isolated from a cold desert of the Indian Himalayas. Int J Syst Evol Microbiol 2005;55:2561-4.

12. Mayilraj S, Suresh K, Schumann P, Kroppenstedt RM, Saini HS. Agrococcus lahaulensis sp. nov. isolated from a cold desert of the Indian Himalayas. Int J Syst Evol Microbiol 2006;56:1807-10.

13. Wang F, Gai Y, Chen M, Xiao X. Arthrobacter psychrochitiniphilus sp. nov. a psychrotrophic bacterium isolated from Antarctica. Int J Syst Evol Microbiol 2009;59:2759-62.

14. Tyagi S, Singh DK. Azospirillum himalayense sp. nov. A nif $\mathrm{H}$ bacterium isolated from Himalayan Valley soil, India. Ann Microbiol 2014;64:259-66.

15. Ghosh A, Bhardwaj M, Satyanarayana T, Khurana M, Mayilraj S, Jain RK, et al. Bacillus lehensis sp. nov. an alkalitolerant bacterium isolated from soil. Int J Syst Evol Microbiol 2007;57:238-42.

16. Isaksen MF, Teske A. Desulforhopalus vacuolatus gen. nov., sp. nov., a new moderately psychrophilic sulfate-reducing bacterium with gas vacuoles isolated from a temperate estuary. Arch Microbiol 1996;166:160-8.

17. Connell LB, Redman R, Rodriguez R, Barrett A, Iszard M, Fonseca Á. Dioszegia antarctica sp. nov. and Dioszegia cryoxerica sp. nov. Psychrophilic basidiomycetous yeasts from polar desert soils in Antarctica. Int J Syst Evol Microbiol 2010;60:1466-1472. 
18. Singh NK, Raichand R, Kaur I, Kaur C, Pareek S, Mayilraj S, et al. Exiguobacterium himgiriensis sp. nov. A novel member of the genus Exiguobacterium, isolated from the Indian Himalayas. Antonie Van Leeuwenhoek 2013;103:789-96.

19. Chaturvedi P, Prabahar V, Manorama R, Pindi PK, Bhadra B, Begum Z, et al. Exiguobacterium soli sp. nov. a psychrophilic bacterium from the mcMurdo dry valleys, Antarctica. Int J Syst Evol Microbiol 2008;58:2447-53.

20. Humphry DR, George A, Black GW, Cummings SP. Flavobacterium frigidarium sp. nov. an aerobic, psychrophilic, xylanolytic and laminarinolytic bacterium from Antarctica. Int J Syst Evol Microbiol 2001;51:1235-43.

21. Zhu F, Wang S, Zhou P. Flavobacterium xinjiangense sp. nov. and Flavobacterium omnivorum sp. nov. novel psychrophiles from the China no 1 glacier. Int J Syst Evol Microbiol 2003;53:853-7.

22. Zhou MY, Zhang YJ, Zhang XY, Yang XD, He HL, Ning D, et al. Flavobacterium phocarum sp. nov. isolated from soils of a seal habitat in Antarctica. Int J Syst Evol Microbiol 2018;68:536-41.

23. Dong K, Liu H, Zhang J, Zhou Y, Xin Y. Flavobacterium xueshanense sp. nov. And Flavobacterium urumqiense sp. nov. two psychrophilic bacteria isolated from Glacier Ice. Int J Syst Evol Microbiol 2012;62:1151-7.

24. Bowman JP, McCammon SA, Brown JL, Nichols PD, McMeekin TA. Psychroserpens burtonensis gen. nov. sp. nov. and Gelidibacter algens gen. nov. sp. nov. psychrophilic bacteria isolated from antarctic lacustrine and Sea Ice habitats. Int J Syst Bacteriol 1997;47:670-7.

25. Holmes DE, Nicoll JS, Bond DR, Lovley DR. Potential role of a novel psychrotolerant member of the family Geobacteraceae, Geopsychrobacter electrodiphilus gen. nov. sp. nov. in electricity production by a marine sediment fuel cell. Appl Environ Microbiol 2004;70:6023-30.

26. Bowman JP, McCammon SA, Brown JL, Mcmeekin TA. Glaciecola punicea gen. nov., sp. nov. and Glaciecola pallidula gen. nov., sp. nov: psychrophilic bacteria from Antarctic sea-ice habitats. Int J Syst Evol Microbiol 1998;48:1213-22.

27. Margesin R, Zhang DC, Frasson D, Brouchkov A. Glaciimonas frigoris sp. nov. a psychrophilic bacterium isolated from ancient siberian permafrost sediment, and emended description of the genus Glaciimonas. Int J Syst Evol Microbiol 2016;66:744-8.

28. Franzmann P, Stackebrandt E, Sanderson K, Volkman J, Cameron D, Stevenson $\mathrm{P}$, et al. Halobacterium lacusprofundi sp. nov., a halophilic bacterium isolated from Deep Lake, Antarctica. Syst Appl Microbiol 1988;11:20-7.

29. Jiang F, Danzeng W, Zhang Y, Zhang Y, Jiang L, Liu J, et al. Hymenobacter rubripertinctus sp. nov. isolated from antarctic Tundra soil. Int J Syst Evol Microbiol 2018;68:663-8.

30. Shen L, Liu Y, Gu Z, Xu B, Wang N, Jiao N, et al. Massilia eurypsychrophila sp. nov. A facultatively psychrophilic bacteria isolated from ice core. Int J Syst Evol Microbiol 2015;65:2124-9.

31. Abyzov S, Filippova S, Kuznetsov V. Nocardiopsis antarcticus a new species of actinomyces isolated from the ice sheet of the Central Antarctica Glacier. Akad Nauk SSSR Izv Biol 1983;4:559-68.

32. Zhou Z, Jiang F, Wang S, Peng F, Dai J, Li W, et al. Pedobacter arcticus sp. nov. a facultative psychrophile isolated from arctic soil, and emended descriptions of the genus pedobacter, Pedobacter heparinus, Pedobacter daechungensis, Pedobacter terricola, Pedobacter glucosidilyticus and Pedobacter lentus. Int J Syst Evol Microbiol 2012;62:1963-9.

33. Carrión O, Miñana-Galbis D, Montes MJ, Mercadé E. Pseudomonas deceptionensis sp. nov. a psychrotolerant bacterium from the Antarctic. Int J Syst Evol Microbiol 2011;61:2401-5.

34. Zachariah S, Kumari P, Das SK. Psychrobacter pocilloporae sp. nov. isolated from a coral, Pocillopora eydouxi. Int J Syst Evol Microbiol 2016;66:5091-8.
35. Shivaji S, Ray M, Rao NS, Saisree L, Jagannadham M, Kumar GS, et al. Sphingobacterium antarcticus sp. nov, a psychrotrophic bacterium from the soils of Schirmacher Oasis, Antarctica. Int J Syst Evol Microbiol 1992;42:102-6.

36. Labrenz M, Tindall BJ, Lawson PA, Collins MD, Schumann P, Hirsch P, et al. Staleya guttiformis gen. nov. sp. nov. and Sulfitobacter brevis sp. nov. alpha-3-proteobacteria from hypersaline, heliothermal and meromictic Antarctic Ekho Lake. Int J Syst Evol Microbiol 2000;50 Pt 1:303-13.

37. Singh RN, Gaba S, Yadav AN, Gaur P, Gulati S, Kaushik R, et al. First high quality draft genome sequence of a plant growth promoting and cold active enzyme producing psychrotrophic arthrobacter agilis strain L77. Stand Genomic Sci 2016;11:54.

38. Hallam SJ, Konstantinidis KT, Putnam N, Schleper C, Watanabe Y, Sugahara $\mathrm{J}$, et al. Genomic analysis of the uncultivated marine crenarchaeote cenarchaeum symbiosum. Proc Natl Acad Sci U S A 2006;103:18296-301.

39. Du Y, Yuan B, Zeng Y, Meng J, Li H, Wang R, et al. Draft genome sequence of the cellulolytic bacterium clavibacter sp. CF11, a strain producing cold-active cellulase. Genome Announc 2015;3: 1304-14.

40. Zhang C, Guo W, Wang Y, Chen X. Draft genome sequences of two psychrotolerant strains, Colwellia polaris MCCC 1C00015 and Colwellia chukchiensis CGMCC 1.9127. Genome Announc 2018;6: e01575-17.

41. Methé BA, Nelson KE, Deming JW, Momen B, Melamud E, Zhang X, et al. The psychrophilic lifestyle as revealed by the genome sequence of Colwellia psychrerythraea $34 \mathrm{H}$ through genomic and proteomic analyses. Proc Natl Acad Sci U S A 2005;102:10913-8.

42. Carneiro AR, Ramos RT, Dall'Agnol H, Pinto AC, de Castro Soares S, Santos AR, et al. Genome sequence of Exiguobacterium antarcticum B7, isolated from a biofilm in Ginger Lake, King George Island, Antarctica. J Bacteriol 2012;194:6689-90.

43. Cai Q, Ye X, Chen B, Zhang B. Complete genome sequence of Exiguobacterium sp. Strain N4-1P, a psychrophilic bioemulsifier producer isolated from a cold marine environment in North Atlantic Canada. Genome Announc 2017;5: e01248-17.

44. Rodrigues DF, Ivanova N, He Z, Huebner M, Zhou J, Tiedje JM, et al. Architecture of thermal adaptation in an Exiguobacterium sibiricum strain isolated from 3 million year old permafrost: A genome and transcriptome approach. BMC Genomics 2008;9:547.

45. Allen MA, Lauro FM, Williams TJ, Burg D, Siddiqui KS, De Francisci D, et al. The genome sequence of the psychrophilic archaeon, Methanococcoides burtonii: The role of genome evolution in cold adaptation. ISME J 2009;3:1012-35.

46. Vollmers J, Voget S, Dietrich S, Gollnow K, Smits M, Meyer K, et al. Poles apart: Arctic and antarctic octadecabacter strains share high genome plasticity and a new type of xanthorhodopsin. PLoS One 2013;8:e63422.

47. Dhar H, Swarnkar MK, Rana A, Kaushal K, Singh AK, Kasana RC, et al. Complete genome sequence of a low-temperature active and alkaline-stable endoglucanase-producing Paenibacillus sp. Strain IHB B 3084 from the Indian trans-Himalayas. J Biotechnol 2016;230:1-2.

48. Salwan R, Swarnkar MK, Singh AK, Kasana RC. First draft genome sequence of a member of the genus Planomicrobium, isolated from the Chandra River, India. Genome Announc 2014;2: e01259-13.

49. Gupta HK, Gupta RD, Singh A, Chauhan NS, Sharma R. Genome sequence of Rheinheimera sp. Strain A13L, isolated from Pangong Lake, India. J Bacteriol 2011;193:5873-4.

50. Saxena AK, Yadav AN, Rajawat M, Kaushik R, Kumar R, Kumar M, et al. Microbial diversity of extreme regions: An unseen heritage and wealth. Indian J Plant Gen Resour 2016;29:246-8.

51. Yadav AN, Saxena AK. Biodiversity and biotechnological applications of halophilic microbes for sustainable agriculture. 
J Appl Biol Biotechnol 2018;6:1-8.

52. Panicker G, Aislabie J, Saul D, Bej AK. Cold tolerance of Pseudomonas sp. 30-3 isolated from oil-contaminated soil, Antarctica. Polar Biol 2002;25:5-11.

53. Foght J, Aislabie J, Turner S, Brown CE, Ryburn J, Saul DJ, et al. Culturable bacteria in subglacial sediments and ice from two southern hemisphere glaciers. Microb Ecol 2004;47:329-40.

54. Saul DJ, Aislabie JM, Brown CE, Harris L, Foght JM. Hydrocarbon contamination changes the bacterial diversity of soil from around Scott Base, Antarctica. FEMS Microbiol Ecol 2005;53:141-55.

55. Chaturvedi P, Shivaji S. Exiguobacterium indicum sp. nov. a psychrophilic bacterium from the hamta glacier of the Himalayan mountain ranges of India. Int J Syst Evol Microbiol 2006;56:2765-70.

56. Cheng SM, Foght JM. Cultivation-independent and dependent characterization of bacteria resident beneath John Evans Glacier. FEMS Microbiol Ecol 2007;59:318-30.

57. Pradhan S, Srinivas TN, Pindi PK, Kishore KH, Begum Z, Singh PK, et al. Bacterial biodiversity from roopkund glacier, Himalayan mountain ranges, India. Extremophiles 2010;14:377-95.

58. Srinivas TN, Singh SM, Pradhan S, Pratibha MS, Kishore KH, Singh AK, et al. Comparison of bacterial diversity in proglacial soil from Kafni Glacier, Himalayan mountain ranges, India, with the bacterial diversity of other glaciers in the world. Extremophiles 2011;15:673-90

59. Cavicchioli R, Charlton T, Ertan H, Omar SM, Siddiqui K, Williams T. Biotechnological uses of enzymes from psychrophiles. Microb Biotechnol 2011;4:449-60.

60. Shivaji S, Pratibha MS, Sailaja B, Hara Kishore K, Singh AK, Begum Z, et al. Bacterial diversity of soil in the vicinity of Pindari Glacier, Himalayan mountain ranges, India, using culturable bacteria and soil 16S rRNA gene clones. Extremophiles 2011;15:1-22.

61. Prasad S, Manasa P, Buddhi S, Tirunagari P, Begum Z, Rajan S, et al. Diversity and bioprospective potential (cold-active enzymes) of cultivable marine bacteria from the subarctic glacial Fjord, Kongsfjorden. Curr Microbiol 2014;68:233-8.

62. Sahay H, Babu BK, Singh S, Kaushik R, Saxena AK, Arora DK, et al. Cold-active hydrolases producing bacteria from two different sub-glacial Himalayan Lakes. J Basic Microbiol 2013;53:703-14.

63. Yadav AN, Sachan SG, Verma P, Saxena AK. Prospecting cold deserts of North Western Himalayas for microbial diversity and plant growth promoting attributes. J Biosci Bioeng 2015;119:683-93.

64. Yadav AN, Sachan SG, Verma P, Tyagi SP, Kaushik R, Saxena AK, et al. Culturable diversity and functional annotation of psychrotrophic bacteria from cold desert of Leh Ladakh (India). World J Microbiol Biotechnol 2015;31:95-108.

65. Yadav AN, Sachan SG, Verma P, Kaushik R, Saxena AK. Cold active hydrolytic enzymes production by psychrotrophic bacilli isolated from three sub-glacial lakes of NW Indian Himalayas. J Basic Microbiol 2016;56:294-307.

66. Yadav AN, Sachan SG, Verma P, Saxena AK. Bioprospecting of plant growth promoting psychrotrophic bacilli from the cold desert of North Western Indian Himalayas. Indian J Exp Biol 2016;54:142-50.

67. Saxena AK, Yadav AN, Kaushik R, Tyagi SP, Shukla L. Biotechnological Applications of Microbes Isolated from Cold Environments in Agriculture and Allied Sectors. In: International Conference on Low Temperature Science and Biotechnological Advances. Society of Low Temperature Biology; 2015. p. 104.

68. Verma P, Yadav AN, Khannam KS, Kumar S, Saxena AK, Suman A. Plant Growth Promotion and Mitigation of Cold Stress in Inoculated Wheat (Triticum aestivum L.) by K-solubilizing Psychrotolerant Methylobacterium phyllosphaerae Strain IARI-HHS2-67. In: Proceeding of International Conference on "Low Temperature Science and Biotechnological Advances. New Delhi-110012, India: Held at NASC Complex; 2015. p. 175.
69. Verma P, Yadav AN, Khannam KS, Kumar S, Saxena AK, Suman A, et al. Molecular diversity and multifarious plant growth promoting attributes of bacilli associated with wheat (Triticum aestivum L.) rhizosphere from six diverse agro-ecological zones of India. J Basic Microbiol 2016;56:44-58.

70. Yadav AN, Verma P, Sachan S, Kaushik R, Saxena A Microbes Mediated Alleviation of Cold Stress for Growth and Yield of Wheat (Triticum aestivum L.). In: Proceeding of International conference on Low Temperature Science and Biotechnological Advances. 2015a. p 179.

71. Yadav AN, Verma P, Singh B, Chauhan VS, Suman A, Saxena AK. Plant growth promoting bacteria: Biodiversity and multifunctional attributes for sustainable agriculture. Adv Biotechnol Microbiol 2017;5:1-16.

72. Yadav AN. Agriculturally important microbiomes: Biodiversity and multifarious PGP attributes for amelioration of diverse abiotic stresses in crops for sustainable agriculture. Biomed J Sci Tech Res 2017;1:1-4.

73. Rana KL, Kour D, Yadav AN, Kumar V, Dhaliwal HS. Biotechnological Applications of Endophytic Microbes Associated with Barley (Hordeum vulgare L.) Growing in Indian Himalayan Regions. In: Proceeding of $86^{\text {th }}$ Annual Session of NASI and Symposium on Science, Technology and Entrepreneurship for Human Welfare in The Himalayan Region; 2016. p. 80.

74. Rana KL, Kour D, Verma P, Yadav AN, Kumar V, Singh DH: Diversity and Biotechnological Applications of Endophytic Microbes Associated with Maize (Zea mays L.) Growing in Indian Himalayan regions. In: Proceeding of National Conference on Advances in Food Science and Technology; 2017.

75. Khalid A, Akhtar M, Mahmood M, Arshad M. Effect of substratedependent microbial ethylene production on plant growth. Microbiology 2006;75:231-6.

76. Verma P, Yadav AN, Kazy SK, Saxena AK, Suman A. Evaluating the diversity and phylogeny of plant growth promoting bacteria associated with wheat (Triticum aestivum) growing in Central Zone of India. Int J Curr Microbiol App Sci 2014;3:432-47.

77. Xu M, Sheng J, Chen L, Men Y, Gan L, Guo S, et al. Bacterial community compositions of tomato (Lycopersicum esculentum Mill.) seeds and plant growth promoting activity of ACC deaminase producing Bacillus subtilis (HYT-12-1) on tomato seedlings. World J Microbiol Biotechnol 2014;30:835-45.

78. Verma P, Yadav AN, Khannam KS, Panjiar N, Kumar S, Saxena AK, et al. Assessment of genetic diversity and plant growth promoting attributes of psychrotolerant bacteria allied with wheat (Triticum aestivum) from the Northern Hills zone of India. Ann Microbiol. 2015:1-15

79. Inderiati S, Franco CM. Isolation and identification of endophytic actinomycetes and their antifungal activity. J Biotechnol Res Trop Reg 2008;1:1-6.

80. Ramesh R, Joshi A, Ghanekar M. Pseudomonads: Major antagonistic endophytic bacteria to suppress bacterial wilt pathogen, Ralstonia solanacearum in the eggplant (Solanum melongena L.). World J Microbiol Biotechnol 2009;25:47-55.

81. Nagendran K, Karthikeyan G, Peeran MF, Raveendran M, Prabakar K, Raguchander T. Management of bacterial leaf blight disease in rice with endophytic bacteria. World Appl Sci J 2013;28:2229-41.

82. Gholami M, Khakvar R, Niknam G. Introduction of some new endophytic bacteria from Bacillus and Streptomyces genera as successful biocontrol agents against Sclerotium rolfsii. Arch Phytopathol Plant Prot 2014;47:122-30.

83. Purnawati A. Endophytic bacteria as biocontrol agents of tomato bacterial wilt disease. J Trop Life Sci 2014;4:33-6.

84. Verma P, Yadav A, Khannam K, Panjiar N, Kumar S, Saxena A, et al. Assessment of genetic diversity and plant growth promoting 
attributes of psychrotolerant bacteria allied with wheat (Triticum aestivum) from the Northern Hills zone of India. Ann Microbiol 2015;3:1-15.

85. Verma P, Yadav AN, Kumar V, Khan A, Saxena AK. Microbes in termite management: Potential role and strategies. In: Khan MA, Ahmad W, editor. Termites and Sustainable Management: Economic Losses and Management. Cham: Springer International Publishing; 2017. p. 197-217.

86. Sahay H, Yadav AN, Singh AK, Singh S, Kaushik R, Saxena AK. Hot springs of Indian Himalayas: Potential sources of microbial diversity and thermostable hydrolytic enzymes. 3 Biotech 2017;7:1-11.

87. Gerday C, Aittaleb M, Bentahir M, Chessa JP, Claverie P, Collins T, et al. Cold-adapted enzymes: From fundamentals to biotechnology. Trends Biotechnol 2000;18:103-7.

88. Groudieva T, Kambourova M, Yusef H, Royter M, Grote R, Trinks H, et al. Diversity and cold-active hydrolytic enzymes of culturable bacteria associated with Arctic Sea Ice, Spitzbergen. Extremophiles 2004;8:475-88.

89. Yadav AN, Sachan SG, Verma P, Suman A, Saxena AK. Diversity of Culturable Psychrotrophic Bacteria from Leh Ladakh and Bioprospecting for Cold-Active Extracellular Enzymes. Conference: National Seminar on "Biotechnological Interventions for the Benefit of Mankind; 2014.

90. Reddy GS, Aggarwal RK, Matsumoto GI, Shivaji S. Arthrobacter flavus sp. nov. a psychrophilic bacterium isolated from a pond in mcMurdo dry Valley, Antarctica. Int J Syst Evol Microbiol 2000;50 Pt 4:1553-61.

91. Reddy GS, Uttam A, Shivaji S. Bacillus cecembensis sp. nov. isolated from the Pindari Glacier of the Indian Himalayas. Int J Syst Evol Microbiol 2008;58:2330-5.

92. Preston CM, Wu KY, Molinski TF, DeLong EF. A psychrophilic crenarchaeon inhabits a marine sponge: Cenarchaeum symbiosum gen. nov. sp. nov. Proc Natl Acad Sci U S A 1996;93:6241-6.

93. Arora PK, Chauhan A, Pant B, Korpole S, Mayilraj S, Jain RK, et al. Chryseomicrobium imtechense gen. nov. sp. nov. a new member of the family Planococcaceae. Int J Syst Evol Microbiol 2011; 61:1859-64.

94. Zhang DC, Wang HX, Cui HL, Yang Y, Liu HC, Dong XZ, et al. Cryobacterium psychrotolerans sp. nov. a novel psychrotolerant bacterium isolated from the China no 1 glacier. Int J Syst Evol Microbiol 2007;57:866-9.

95. Reddy GS, Pradhan S, Manorama R, Shivaji S. Cryobacterium roopkundense sp. nov. a psychrophilic bacterium isolated from glacial soil. Int J Syst Evol Microbiol 2010;60:866-70.

96. Chaturvedi P, Reddy GS, Shivaji S. Dyadobacter hamtensis sp. nov. from hamta glacier, located in the Himalayas, India. Int J Syst Evol Microbiol 2005;55:2113-7.

97. Mou YZ, Qiu XX, Zhao ML, Cui HL, Oh D, Dyall-Smith ML, et al. Halohasta litorea gen. nov. Sp. nov. and Halohasta litchfieldiae sp. nov. isolated from the daliang aquaculture farm, China and from Deep Lake, Antarctica, respectively. Extremophiles 2012;16:895-901.

98. Mayilraj S, Kroppenstedt RM, Suresh K, Saini HS. Kocuria himachalensis sp. nov. an actinobacterium isolated from the Indian Himalayas. Int J Syst Evol Microbiol 2006;56:1971-5.

99. Gosink J, Herwig R, Staley J. Octadecabacter arcticus gen. nov., sp. nov., and $O$. antarcticus, sp. nov., nonpigmented, psychrophilic gas vacuolate bacteria from polar Sea Ice and water. Syst Appl Microbiol 1997;20:356-65.

100. Yakimov MM, Giuliano L, Gentile G, Crisafi E, Chernikova TN, Abraham WR, et al. Oleispira antarctica gen. nov. sp. nov. a novel hydrocarbonoclastic marine bacterium isolated from Antarctic Coastal Sea water. Int J Syst Evol Microbiol 2003;53:779-85.

101. Mayilraj S, Saha P, Suresh K, Saini HS. Ornithinimicrobium kibberense sp. nov., isolated from the Indian Himalayas. Int J Syst Evol Microbiol 2006;56:1657-61.
102. Irgens RL, Gosink JJ, Staley JT. Polaromonas vacuolata gen. nov. sp. nov. a psychrophilic, marine, gas vacuolate bacterium from Antarctica. Int J Syst Bacteriol 1996;46:822-6.

103. López NI, Pettinari MJ, Stackebrandt E, Tribelli PM, Põtter M, Steinbüchel A, et al. Pseudomonas extremaustralis sp. nov. a poly(3hydroxybutyrate) producer isolated from an Antarctic environment. Curr Microbiol 2009;59:514-9.

104. Bowman JP, McCammon SA, Lewis T, Skerratt JH, Brown JL, Nichols DS, et al. Psychroflexus torquis gen. nov. sp. nov. a psychrophilic species from Antarctic Sea Ice, and reclassification of Flavobacterium gondwanense (Dobson et al 1993) as Psychroflexus gondwanense Gen. nov. comb. nov. Microbiology 1998;144 Pt 6:1601-9.

105. Miyazaki M, Nogi Y, Fujiwara Y, Horikoshi K. Psychromonas japonica sp. nov. Psychromonas aquimarina sp. nov. Psychromonas macrocephali sp. nov. and Psychromonas ossibalaenae sp. nov. psychrotrophic bacteria isolated from sediment adjacent to sperm whale carcasses off Kagoshima, Japan. Int J Syst Evol Microbiol 2008;58:1709-14.

106. Anil Kumar P, Srinivas TN, Sasikala Ch, Ramana ChV. Rhodobacter changlensis sp. nov. a psychrotolerant, phototrophic Alphaproteobacterium from the Himalayas of India. Int J Syst Evol Microbiol 2007;57:2568-71.

107. Shivaji S, Bhadra B, Rao RS, Pradhan S. Rhodotorula himalayensis sp. nov. a novel psychrophilic yeast isolated from roopkund lake of the Himalayan mountain ranges, India. Extremophiles 2008;12:375-81.

108. Bowman JP, McCammon SA, Nichols DS, Skerratt JH, Rea SM, Nichols PD, et al. Shewanella gelidimarina sp. nov. and Shewanella frigidimarina sp. nov. novel antarctic species with the ability to produce eicosapentaenoic acid (20:5 omega 3) and grow anaerobically by dissimilatory fe(III) reduction. Int J Syst Bacteriol 1997;47:1040-7.

109. Albert RA, Waas NE, Pavlons SC, Pearson JL, Ketelboeter L, Rosselló-Móra R, et al. Sphingobacterium psychroaquaticum sp. nov. a psychrophilic bacterium isolated from lake Michigan water. Int J Syst Evol Microbiol 2013;63:952-8.

110. Swarnkar MK, Salwan R, Kasana RC, Singh AK. Draft genome sequence of psychrotrophic Acinetobacter sp. Strain MN12 (MTCC 10786), which produces a low-temperature-active and alkaline-stable peptidase. Genome Announc 2014;2: e01167-14.

111. Lylloff JE, Hansen LB, Jepsen M, Hallin PF, Sørensen SJ, Stougaard P, et al. Draft genome sequences of two protease-producing strains of Arsukibacterium, isolated from two cold and alkaline environments. Genome Announc 2015;3: e00585-15.

112. Kumar R, Singh D, Swarnkar MK, Singh AK, Kumar S. Complete genome sequence of Arthrobacter alpinus ERGS4:06, a yellow pigmented bacterium tolerant to cold and radiations isolated from Sikkim Himalaya. J Biotechnol 2016;220:86-7.

113. Kiran S, Swarnkar MK, Pal M, Thakur R, Tewari R, Singh AK, et al. Complete genome sequencing of protease-producing novel Arthrobacter sp. Strain IHBB 11108 using pacBio single-molecule real-time sequencing technology. Genome Announc 2015; 3:e00346-15.

114. Reddy GS, Sreenivas A, Shivaji S. Draft genome sequence of Cryobacterium roopkundensis strain ruGl7, isolated from a soil sample in the vicinity of Roopkund Lake, Himalayas, India. Genome Announc 2014;2:e01206-14.

115. Koo H, Ptacek T, Crowley M, Swain AK, Osborne JD, Bej AK, et al. Draft genome sequence of Hymenobacter sp. Strain IS2118, isolated from a freshwater lake in Schirmacher Oasis, Antarctica, reveals diverse genes for adaptation to cold ecosystems. Genome Announc 2014;2:e0739-14.

116. Gupta HK, Singh A, Sharma R. Genome sequence of Idiomarina sp. Strain A28L, isolated from Pangong Lake, India. J Bacteriol 2011;193:5875-6. 
117. Himanshu, Swarnkar MK, Singh D, Kumar R. First complete genome sequence of a species in the genus Microterricola, an extremophilic cold active enzyme producing bacterial strain ERGS5:02 isolated from Sikkim Himalaya. J Biotechnol 2016;222:17-8.

118. Singh P, Kapse N, Roy U, Singh SM, Dhakephalkar PK. Draft genome sequence of permafrost bacterium Nesterenkonia sp. Strain PF2B19, revealing a cold adaptation strategy and diverse biotechnological potential. Genome Announc 2017;5:e0133-17.

119. Dhar H, Swarnkar MK, Gulati A, Singh AK, Kasana RC. Draft genome sequence of a cellulase-producing psychrotrophic Paenibacillus strain, IHB B 3415, isolated from the cold environment of the Western Himalayas, India. Genome Announc 2015;3:e01581-14.

120. Gulati A, Swarnkar MK, Vyas P, Rahi P, Thakur R, Thakur N, et al. Complete genome sequence of the rhizobacterium Pseudomonas trivialis strain IHBB745 with multiple plant growth-promoting activities and tolerance to desiccation and alkalinity. Genome Announc 2015;3: e00943-15.

121. Baker E, Wang B, Bellora N, Peris D, Hulfachor AB, Koshalek JA, et al. The genome sequence of Saccharomyces eubayanus and the domestication of lager-brewing yeasts. Mol Biol Evol 2015;32:2818-31.

122. Mishra A, Jha G, Thakur IS. Draft genome sequence of Zhihengliuella sp. Strain ISTPL4, a psychrotolerant and halotolerant bacterium isolated from Pangong Lake, India. Genome Announc 2018; 6:e01533-17.

123. Verma P, Yadav AN, Shukla L, Saxena AK, Suman A. Alleviation of cold stress in wheat seedlings by Bacillus amyloliquefaciens IARIHHS2-30, an endophytic psychrotolerant K-solubilizing bacterium from NW Indian Himalayas. Natl J Life Sci 2015;12:105-10.

124. Selvakumar G, Kundu S, Joshi P, Nazim S, Gupta A, Mishra P, et al.
Characterization of a cold-tolerant plant growth-promoting bacterium Pantoea dispersa 1A isolated from a sub-alpine soil in the North Western Indian Himalayas. World J Microbiol Biotechnol 2008; 24:955-60

125. Gulati A, Rahi P, Vyas P. Characterization of phosphate-solubilizing fluorescent pseudomonads from the rhizosphere of seabuckthorn growing in the cold deserts of Himalayas. Curr Microbiol 2008; 56:73-9.

126. Mishra PK, Bisht SC, Ruwari P, Selvakumar G, Joshi GK, Bisht JK, et al. Alleviation of cold stress in inoculated wheat (Triticum aestivum $\mathrm{L}$.) seedlings with psychrotolerant pseudomonads from $\mathrm{NW}$ Himalayas. Arch Microbiol 2011;193:497-513.

127. Selvakumar G, Joshi P, Nazim S, Mishra P, Bisht J, Gupta H. Phosphate solubilization and growth promotion by Pseudomonas fragi CS11RH1 (MTCC 8984), a psychrotolerant bacterium isolated from a high altitude Himalayan rhizosphere. Biologia 2009; 64:239-45.

128. Mishra PK, Mishra S, Selvakumar G, Bisht SC, Bisht JK, Kundu S, et al. Characterisation of a psychrotolerant plant growth promoting Pseudomonas sp. strain PGERs17 (MTCC 9000) isolated from North Western Indian Himalayas. Ann Microbiol 2008;58:561-8.

129. Vyas P, Joshi R, Sharma KC, Rahi P, Gulati A, Gulati A, et al. Coldadapted and rhizosphere-competent strain of Rahnella sp. With broad-spectrum plant growth-promotion potential. J Microbiol Biotechnol 2010;20:1724-34.

\section{How to cite this article:}

Yadav AN, Yadav N, Sachan SG, Saxena AK. Biodiversity of

psychrotrophic microbes and their biotechnological applications. J App Biol Biotech. 2019; 7(04):99-108. DOI: 10.7324/JABB.2019.70415 